\title{
Down syndrome in Israel
}

\author{
Joav Merrick \\ Office of the Medical Director, Division for the Mentally Retarded, Ministry of Labour and Social Affairs, State \\ of Israel, Jerusalem
}

\begin{abstract}
The incidence of Down syndrome was studied in Jerusalem for the years 1964-1970 showing an overall incidence rate of 2.43 per I,000 live births. A National Down Syndrome Register was established in 1978 and data on annual incidence and mortality rates from 1979-1997 is presented. The incidence in 1997 was I.0 per I,000 live births, but 2.32 per I,000, when live births and terminated pregnancies are summed. Infant mortality has generally decreased in the past 20 years in Israel, and a decrease in infant mortality in Down syndrome has also been noted. This is due to better medical treatment and increased parental involvement in the care for infants with Down syndrome.
\end{abstract}

Keywords — National Down Syndrome Register, incidence rates, infant mortality, Israel

\section{Introduction}

There has been a decline in infant mortality in Israel over the last 25 years. In 1997 the infant mortality rate for Jews was 4.9 per 1,000 live births, whereas for Arabs it was 9.3 resulting in a total rate of 6.2 (Ifrah, 1999).

This decline affects Jews as well as Arabs, with an especially marked decline in mortality due to infectious causes.

Congenital malformation continues to be the commonest cause of infant mortality athough there has been a $61 \%$ decrease among Jews (and 38\% decrease among Arabs) in mortality from this cause since 1970. Contributing causes for the difference between Jews and Arabs could be due to the higher extent of consanguineous marriage in the Arab population and a lower utilisation of prenatal screening.

\section{Prenatal screening}

Screening tests for carriers of the Tay-Sachs gene started in 1974, and in 1978 a national program for the prevention of births defects was implemented by the Ministry of Health. Since 1979 data has been collected and analyzed on the births of infants with Down syndrome. The Down Syndrome National Register receives information from routine notifications from delivery rooms, cytogenetic laboratories in all hospitals and annual reports from hospital nurseries.

In 1978 free amniocentesis was offered to women over the age of 37 years, but since 1993 the age limit has been reduced to 35 years. The use of amniocentesis was $61 \%$ in pregnant Jewish women (over 35 years) in 1997 and 14\% in younger women with a total $22.2 \%$ of all pregnant Jewish women. For Arab women the total utilisation was $4.2 \%$ (Ifrah, 1999). The use of amniocentesis in the target group of women over 35 years is higher than in other countries (England, the United States, Holland, Australia), where Steele and Stratford (1995) found no more than 50\% utilization.

In $1990,53 \%$ of the cases of Down syndrome among Jewish women were detected and terminated during pregnancy, whereas in 1997 this percentage had increased to $61.2 \%$. In the Arab population $8 \%$ of pregnancies with Down syndrome were terminated in 1991, whereas in 1997 that figure had increased to $35.7 \%$ (Ifrah, 1999).

In 1997 , there were 86,140 births among Jewish women and 38,338 amongst Arab women with the number of amniocenteses performed being 19,135 and 1,607 for Jewish and Arab women respectively. The total number of cases of Down syndrome diagnosed antenatally was 219 cases among Jewish women and 70 among Arab women. There were 85 live births among Jewish women and 45 live births among Arab women and 134 terminations among Jewish women and 25 terminations among Arab women during this period (Ifrah, 1999). 


\begin{tabular}{|cccccccc|}
\hline Maternal age bands in years \\
\hline $15-19$ & $20-24$ & $25-29$ & $30-34$ & $35-39$ & $40-44$ & $>45$ & Total rate \\
1.08 & 0.73 & 1.50 & 2.17 & 5.79 & 17.95 & 15.08 & 2.43
\end{tabular}

Table I. Incidence rates (per I,000 births) of Down syndrome in Jerusalem 1964-1970. infants with Down syndrome between the years 1964-1970. The incidence rates according to maternal age can be seen in Table 1 . The overall incidence rate for the period was 2.43 per 1,000 births with a tendency to increasing incidence with increase in maternal age. This rate is higher than some other countries during the same period, e.g. Australia (1.19), England (1.39) and the United States (1.44) (Steele, 1996).

The Ministry of Health in Israel started a National Program for Detection and Prevention of Birth Defects in 1974 and has collected data on Down syndrome since 1979. The number of live births and the incidence rate for Jews and non-Jews is shown in Table 2 (Klein et al., 1998). The total or true incidence rate for Down syndrome in 1997, including both live births and terminated pregnancies, for Jews and non-Jews was 2.32 per 1,000 . This rate is not appreciably different from the rate found for the years 1964-1970 (Harlap, 1973), namely 2.43.

\section{Trends in mortality}

About $85 \%$ of deaths due to congenital malformations occur during the first year and a further $10 \%$ during the second to fourth years of the child's life. In 1995 the mortality rates in the 0-4 age group were 39.7 per 100,000 for Jewish males, 27.4 for Jewish females and, 89.2 for

\begin{tabular}{|lccc|}
\hline Year & $\begin{array}{l}\text { Total number } \\
\text { of live births } \\
\text { with Down } \\
\text { syndrome }\end{array}$ & $\begin{array}{c}\text { Rate per } \\
\text { I,000 live } \\
\text { births for } \\
\text { Jews }\end{array}$ & $\begin{array}{c}\text { Rate per } \\
\text { I,000 live } \\
\text { births for } \\
\text { non-Jews }\end{array}$ \\
\hline 1979 & 109 & 1.1 & 1.5 \\
1980 & 107 & 1.0 & 1.4 \\
1981 & 111 & 1.1 & 1.5 \\
1982 & 128 & 1.3 & 1.5 \\
1983 & 125 & 1.3 & 1.2 \\
1984 & 120 & 1.2 & 1.3 \\
1985 & 131 & 1.3 & 1.4 \\
1986 & 131 & 1.3 & 1.3 \\
1987 & 130 & 1.5 & 0.9 \\
1988 & 123 & 1.3 & 0.9 \\
1989 & 116 & 1.1 & 1.2 \\
1990 & 103 & 1.0 & 1.1 \\
1991 & 97 & 1.0 & 0.8 \\
1992 & 115 & 0.7 & 1.8 \\
1993 & 114 & 0.9 & 1.3 \\
1994 & 96 & 0.7 & 1.2 \\
1995 & 107 & 0.8 & 1.2 \\
1996 & 105 & 0.9 & 0.9 \\
1997 & 130 & 1.0 & 1.2 \\
\hline Table 2. Total number of live birth persons with \\
Down syndrome and incidence rates for Jews and \\
non-Jews in Israel 1979-1997.
\end{tabular}

\begin{tabular}{|ccc|}
\hline Year & $\begin{array}{c}\text { Number of } \\
\text { deaths }\end{array}$ & $\begin{array}{c}\text { Percentage } \\
\text { of total }\end{array}$ \\
\hline 1979 & 50 & 45.9 \\
1980 & 52 & 48.6 \\
1981 & 35 & 31.5 \\
1982 & 41 & 32.0 \\
1983 & 34 & 27.2 \\
1984 & 33 & 27.5 \\
1985 & 23 & 17.6 \\
1986 & 25 & 19.1 \\
1987 & 22 & 16.9 \\
1988 & 23 & 18.7 \\
1989 & 24 & 20.7 \\
1990 & 14 & 13.6 \\
1991 & 13 & 13.4 \\
1992 & 22 & 19.1 \\
1993 & 22 & 19.3 \\
1994 & 10 & 10.4 \\
1995 & 11 & 10.3 \\
1996 & 9 & 8.6 \\
& & \\
\hline Table 3. Infant mortality (until \\
year one) for children with Down \\
syndrome in Israel I979-1996. \\
\end{tabular}

\begin{tabular}{|c|c|c|}
\hline Year & $\begin{array}{l}\text { Number of } \\
\text { deaths }\end{array}$ & $\begin{array}{l}\text { Percentage } \\
\text { of total }\end{array}$ \\
\hline 1979 & 63 & 57.8 \\
\hline 1980 & 64 & 59.8 \\
\hline |98| & 44 & 39.6 \\
\hline 1982 & 54 & 42.2 \\
\hline 1983 & 43 & 34.4 \\
\hline 1984 & $4 I$ & 34.2 \\
\hline 1985 & 39 & 29.8 \\
\hline 1986 & 40 & 30.5 \\
\hline 1987 & 33 & 25.4 \\
\hline 1988 & 35 & 28.5 \\
\hline 1989 & 36 & 31.0 \\
\hline 1990 & 27 & 26.2 \\
\hline $199 \mid$ & 21 & 21.6 \\
\hline 1992 & 32 & 27.8 \\
\hline 1993 & 28 & 24.6 \\
\hline 1994 & 14 & 14.6 \\
\hline 1995 & 13 & 12.1 \\
\hline 1996 & II & 10.5 \\
\hline \multicolumn{3}{|c|}{$\begin{array}{l}\text { Table 4. Mortality of children with } \\
\text { Down syndrome until age I4 in } \\
\text { Israel I979-1996. }\end{array}$} \\
\hline
\end{tabular}

males and 80.9 for females in the Arab population. Mortality due to congenital malformations declined in the years 1970-1995 by $70 \%$ for Jewish males, $76 \%$ for Jewish females and $47 \%$ for Arab males and $46 \%$ for Arab females (Ifrah, 1999).

Infant mortality (deaths until the end of the first year) for children with Down syndrome is shown in Table 3 and mortality up to the age of 14 years is shown in Table 4 (Klein et al., 1998).

These figures demonstrate a clear decrease in mortality since 1979. This decrease is caused by several factors. Firstly, because of technical developments in medicine, such as improved surgical techniques for cardiac and gastrointestinal malformations. Secondly, earlier and more effective medical treatment of infections and thirdly, a change in attitude both by parents, and also by medical and nursing staff in hospitals towards a much more positive attitude towards children born with Down syndrome (Sadetzki et al., 1999a, Sadetzki et al., 1999b). 


\section{Conclusion}

The total incidence of Down syndrome during the years 1964 through 1970 was found to be 2.43 per 1,000 live births. Data from the National Down Syndrome Register for the years 1979 through 1997 showed a decline in the incidence, but when live births and terminated pregnancies were summed the true incidence rate in 1997 was 2.32 . Mortality rates have shown a clear decline since 1979 due to medical advances, but also due to a much more positive public attitude towards persons with Down syndrome in Israeli society.

\section{Correspondence}

Professor Joav Merrick, MD, DMSc, Medical Director,

Division for the Mentally Retarded, BOX 1260, IL-91012

Jerusalem, Israel•E-mail jmerrick@aquanet.co.il

\section{References}

Harlap, S. (1973). Down syndrome in West Jerusalem. American Journal of Epidemiology, 97, 225-232.

Ifrah, A. (Ed.) (1999). Health Status in Israel 1999. Tel Hashomer: Israel Center for Disease Control.

Klein, H., Aburbeh, M., Bentolila, M., Shtein, N., Gordon, S. \& Haklai, Z. (1998). Health in Israel. Selected Data. Jerusalem: Ministry of Health.

Sadetzki, S., Chetrit, A., Akstein, E., Luxenburg, O., Keinan, L., Litvak, I. \& Modan, B. (1999a). Risk factors for infant mortality in Down syndrome. A nationwide study. (unpublished data).

Sadetzki, S., Chetrit, A., Keinan, L., Luxenburg, O. \& Modan, B. (1999b). Disposition of infants with Down syndrome. (unpublished data).

Steele, J. \& Stratford, B. (1995). The United Kingdom population with Down syndrome: Present and future projections. American Journal on Mental Retardation, 99 (6), 664-682.

Steele, J. (1996). Epidemiology: Incidence, prevalence and size of the Down's syndrome population. In B. Stratford and P. Gunn (eds), New Approaches to Down syndrome. London: Cassell. pp. 45-72. 